\title{
The Effectiveness of Emergency Response System's Service Providers for Road Accidents in Johor Bahru, Malaysia
}

\author{
Mustaffa, A.A. ${ }^{1}$ and Kazunori, H. ${ }^{2}$
}

\begin{abstract}
In Malaysia, there are three core services involved in emergency, namely the fire and rescue, police, and ambulance services. The aim of the service providers is to prevent the loss of life and damage by improving their response time. The Civil Defence Department and the 999 call centre also assist the main providers. This paper aims to provide an overview of emergency response system (ERS) for road accidents in Johor Bahru. The objective is to find the effective services from ERS works. There are three sections of chronological events involved: the call centre receiving reports on accidents, at location of the accident and the time during which the victims are brought to the hospital. The paper studies the operation scheme of the ERS by describing the condition; to analyse the questionnaire using a set of questions on the ERS service; and to determine the effectiveness of the services provided. The provider's services can be identified as a main factor in improving the ERS services provided in the study area.
\end{abstract}

Keywords: ERS provider, ERS services, Road accident management.

\section{Introduction}

Recently, there has been a worldwide interest in developing efficient and effective systems for road accident management because of the high cost of traffic congestions caused by incidents. Traffic congestions needs to be well-managed to minimize traffic delays. The emergency service providers must arrive promptly at accident locations according to the information given and be able to provide the appropriate responses in terms of providing emergency rescue. Malaysia has, during the past decade, experienced a growth in population at an average rate of about $3 \%$ per year. The increase has led to a consequent rise in the number of road accidents. In addition, a new road safety procedure was established to specifically plan, coordinate, implement; and evaluate the response actions to ensure the road safety in the country [1]. In Malaysia, the providers of ERS, are: police, fire and rescue, hospital ambulance, Civil Defence Department and call centre. Each provider developed its own emergency cases reaction systems. Consequently, there exist no (or poor) coordination in the implementation of the ERS. The shortcoming are made worse by the absence of efforts among the administrators to improve the coordination between different providers, resulting in the ineffective performance of the ERS $[2,3]$.

\footnotetext{
${ }^{1}$ Faculty of Civil and Environmental Engineering, Universiti Tun Hussein Onn, MALAYSIA. Email: mustafa@uthm.edu.my ${ }^{2}$ Department of Civil Engineering and Architecture, Saga University, JAPAN.
}

Note: Discussion is expected before November, $1^{\text {st }} 2012$, and will be published in the "Civil Engineering Dimension", volume 15, number 1, March 2013.

Received 29 September 2011; revised 14 March 2012; accepted 15 June 2012
The ERS plays a prominent role in public services despite the pressure of the demand for quality services. There are many researches which embarked on the evaluation of services, many of which are focused on public satisfaction. The government has made efforts to improve emergency services. However, there are no studie savailable which can identify the operation scheme of the services. Therefore, it is the aim of this study to identify the effective services from some of the providers. To identify the type of services, the study used some questionnaires to obtain the relevant data from providers. The questionnaires evaluates the three parts of the service previously mentioned - the service by the call centre, the service provided at the location of the accident and the service provided during the delivery of the victims to the hospital. The study found the overall effectiveness is moderate and there is much room for improvement.

This paper is organised to begin with an overview of the ERS in Malaysia, followed by a discussion on the methods applied and then a section concerning the results of analysis. Discussions on the results are then reported which are then followed by an explanation on the limitations of the research and finally a conclusion is presented to summarise all the aforementioned discussions including some suggestions to improve the services of ERS .

\section{Overview of ERS in Malaysia}

Malaysia is a developing country consisting of fifteen states and a total area of 329,847 square kilometres. Malaysia is separated by the South China Sea into two regions, the peninsular (mainland) and the Eastern part (Sabah and Sarawak on the Borneo 
Island). Borders are shared with Thailand, Indonesia, Brunei, Singapore, Vietnam, and the Philippines. The infrastructures of Malaysia are one of the most developed in Asia. Malaysia's road network covers approximately 98,721 kilometres. The rapid development of the road network and the escalating number of vehicles on Malaysian roads caused increasing number of road accidents involving fatal and serious injuries [3]. All emergency providers have a system in place for conducting the emergency response. There are three core providers involved emergency services provision. The fire and rescue service deals with potentially harmful fires, rescue operations, and the road traffic collisions. The police services concern security of persons and properties covering all categories of emergencies. The ambulance service aims to reduce loss of life and damage by reducing response time. Other providers Civil Defence Department and volunteer organisations are there to assist the three main providers [4].

Malaysian Emergency Rescue Services (MERS 999) is the single call centre service for emergency with a single number i.e. 999. Firstly, calls should be made to the MERS 999 call centre or directly to the specific emergency services provider when road traffic accidents (RTA) occur. The MERS 999 call centre then verifies and filters the call. Once the call is analysed and confirmed, the information is then forwarded to the relevant provider based on the emergency incident. All providers will receive the call along with a callcard. The call centre in each provider receives the call and gives an order to rescue teams based on the relevant information. The rescue team will move to the scene as soon as possible. Once all the works at the scene have finished, the ambulance will transport the victim to the nearest hospital. This is the standard operating procedures (SOP) applied by all emergency services providers.

The government has made attempts to improve emergency services in Malaysia and it should be consistent with the public needs. Previous studies for evaluation of ERS cover only on the satisfaction of the public regarding the emergency services, and the study of satisfaction among patients on the Emergency Medical Services (EMS) at hospitals all over Malaysia [2,3,5,6,7]. There is no survey report concerning emergency services providers in Malaysia, except for the study about the EMS. Therefore, this paper attempts to study the ERS from the perspectives of the service providers to provide another angle of viewpoint on the emergency response in the current time. The emergency service is extremely significant and the study on the subject matter is very urgent. It can be an indicator of the quality of the ERS.

The services of ERS must be capable of generating public satisfaction especially among the victims.
With the ineffective and inefficient coordination among providers during an emergency situation, coupled with the absence of uniform communication and dispatching procedures involving all providers is the main problem for ERS in Malaysia [8]. Nevertheless, the public demands better emergency response so that the total number of victims (casualties/ injuries) caused by the road accidents will decrease although the total number of accident increases annually [1]. Currently, the ERS in Malaysia have yet to be evaluated to identify the sufficient quality of response and what is needed to fulfil the public needs. To examine the performance of the existing ERS application by the providers, questionnaires were distributed among employees of the service providers within the study area.

\section{Research Methodologies}

There are several studies conducted in Malaysia on emergency responses, such as on patient satisfaction with ambulance services [2]; patient satisfaction with response time [6]; patient satisfaction with emergency department [5]. All these studies involved the EMS, but they did not involve other emergency provider.

This is the first study focussing on the provider of emergency services in the study area. This paper aims to provide an overview regarding the performance of ERS for road accidents in Johor Bahru, Johor, Malaysia. The main objective is to find the most effective services within the ERS. Surveys were conducted during a two-month period between September and October of 2010 involving a total of 79 respondents. The survey was conducted using online questionnaires sent to respondents via e-mail. The respondents were asked to answer a set of questions regarding the services provided by the providers during the emergency situations. In some parts of the questionnaire, they were presented with statements and were asked to rate based on a Likert Scale (from 1 to 5 scale; where 1 is highly dissatisfied and 5 is highly satisfied). The questionnaire was divided into 5 different parts namely: demographic; call handling services of ERS provider; services provided at the scene; provision and efficiency of transportation services to the hospital; and the providers' suggestion. Statistical analyses were conducted using the Statistical Package for Social Science (SPSS) version 17.0.

\section{Results}

\section{Demographics}

In Table 1, the age of the respondents was summarised as follows: $40.5 \%$ (32) of respondents were between the age of 21 and 30 years old; $10.1 \%$ (8) respondents were over 51 years of age; and only $1.3 \%$ 
(1) of respondents were aged below 21. On the occupations of the respondents, $19.0 \%$ (15) of them were policemen; the percentage of those serving in the fire and rescue department was $22.8 \%(18)$ $20.3 \%$ (16) work at hospitals; civil defence employees were $19.0 \%$ (15); and centre $19.0 \%$ (15) of them work at MERS 999 call centres.

Table 1. The Characteristics of Respondent Demographic

\begin{tabular}{llrr}
\hline Variable & \multicolumn{1}{c}{ Category } & $\begin{array}{r}\text { Frequ- } \\
\text { ency }\end{array}$ & Percent \\
\hline Age & $<21$ & 1 & 1.3 \\
& $21-30$ & 32 & 40.5 \\
& $31-40$ & 21 & 26.6 \\
& $41-50$ & 17 & 21.5 \\
Provider & $51-64$ & 8 & 10.1 \\
& Police & 15 & 19.0 \\
& Fire and rescue & 18 & 22.8 \\
& Hospital & 16 & 20.3 \\
& Civil defence & 15 & 19.0 \\
Position & MERS 999 centre & 15 & 19.0 \\
& Call operator & 5 & 6.3 \\
Involve with ERS & Emergency staff & 39 & 49.4 \\
& Emergency supervisor & 35 & 44.3 \\
& 2- 5 years & 11 & 13.9 \\
& 6-10 years & 32 & 40.5 \\
& 11-20 years & 19 & 24.1 \\
& $>20$ years & 9 & 11.4 \\
& & 8 & 10.1 \\
& & 79 & 100.0 \\
\hline
\end{tabular}

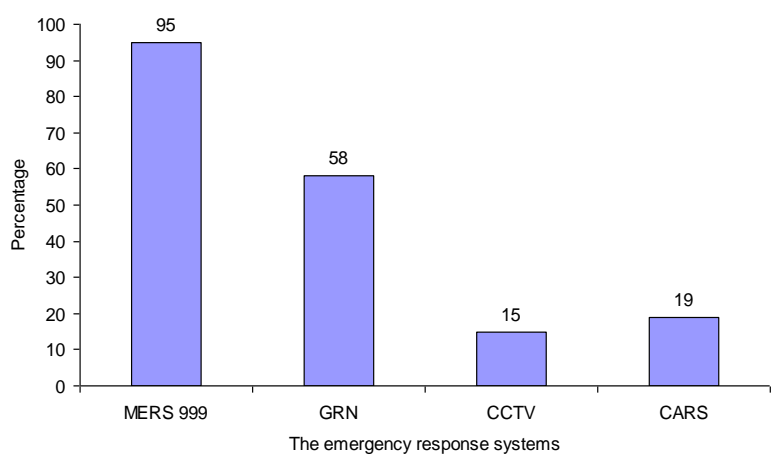

Figure 1. The Handling Systems for ERS

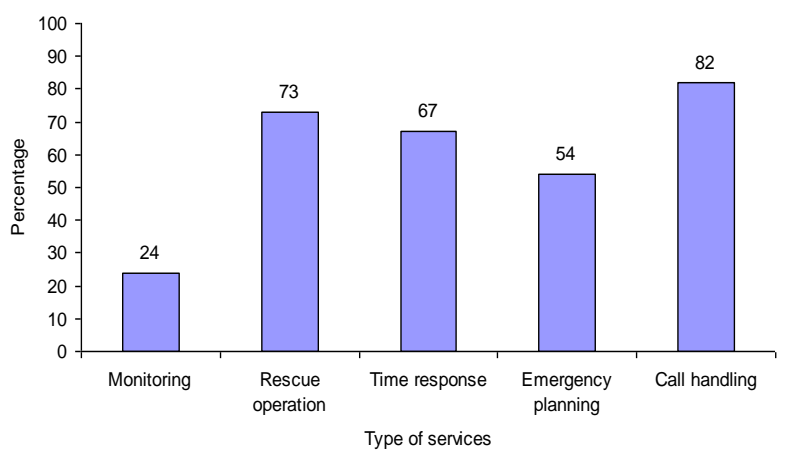

Figure 2. Type of ERS Services
Most of the respondents were emergency staffs and supervisors with percentage of 49.4\% (39) and 44.3\% (35) respectively compared to only $6.3 \%$ (5) of them who are call operators. The results of the questionnaire also include the tenure of service among the respondents in the ERS. The findings are as follows: $13.9 \%$ (11) have served for less than two years; $40.5 \%$ (32) has been with their employers for two to five years; $24.1 \%$ (19) have served for six to ten years; $11.4 \%$ (9) with tenure of service of 11-20 years; and $10.1 \%$ (8) with more than 20 years of service.

The respondents were asked whether they are aware of the ERS currently in practice. Figure 1 shows that 95\% (75) respondent know well about MERS 999, $58 \%$ (46) respondents are aware about Government Integrated Radio Network (GIRN), 15\% (12) respondents have some knowledge about integrated CCTV systems, and 19\% (15) respondents know about Computerized Accident Recording System (CARS). Figure 2 reports the type of services within the ERS involving all providers which involves the participation of the respondents. 82\% (65) respondents are involved in handling emergency calls; 73\% (58) respondents are involved in rescue operations; $67 \%$ (53) respondents' jobs concern response time; $54 \%$ (43) respondents have their hands in emergency planning; and only $24 \%$ (19) respondents handle vehicle monitoring in ERS operations.

\section{The Call Centre Services}

The call centre is the first to receive information immediately after an accident occurs. This indicates the great importance of call centre in providing a prompt response to emergency incidents. Table 2 presents the frequency of call handling by different service providers. The MERS 999 receive the highest number of calls each day (21-50 calls), followed by hospitals, the Fire and Rescue Department. Meanwhile, the Civil Defence and the police receive less than 20 calls every day.

Table 2. The Number of Emergency Call Handling by Providers

\begin{tabular}{lrrrr}
\hline \multirow{2}{*}{ Agencies } & \multicolumn{4}{c}{ No. of emergency call per day } \\
\cline { 2 - 5 } & $<10$ & $10-20$ & $21-50>$ & $\mathrm{N}$ \\
\hline MERS 999 call centre & 0 & 0 & 15 & 15 \\
Hospital/Ambulance & 1 & 3 & 12 & 16 \\
Fire and rescue & 4 & 11 & 3 & 18 \\
Civil defence & 8 & 7 & 0 & 15 \\
Police & 10 & 5 & 0 & 15 \\
\hline Valid N (list wise) & 23 & 26 & 30 & 79 \\
\hline
\end{tabular}


Upon receiving the emergency calls, staffs at the call centres will handle the call according to their standard operating procedure (SOP). In the questionnaire, the respondents $(\mathrm{N}=79)$ were asked about their experience, ability and responsibility in handling emergency calls using statements which must be rated based on a Likert scale of 1 to 5 (strongly agree to strongly disagree). Table 3 shows the percentages and frequencies factors involved in handling emergency calls. More than 80 percent agreed with statements Q11b 86.08\% (69), Q11a 84.81\% (67) and Q10e 83.54\% (66). Other percenttages of 'strongly agree' answers recorded (in descending order) were: $62.03 \%$ (49) for Q10a; $62.03 \%$ (49) for Q10c; 48.10\% (38) for Q11c; 48.10\% (38) for Q11d; 40.51\% (32) for Q10d; and 36.71\% (29) for Q10b. The number in brackets is the frequency of respected statement. These positive responses to the statements given were an indication of the good services provided by the call centres.

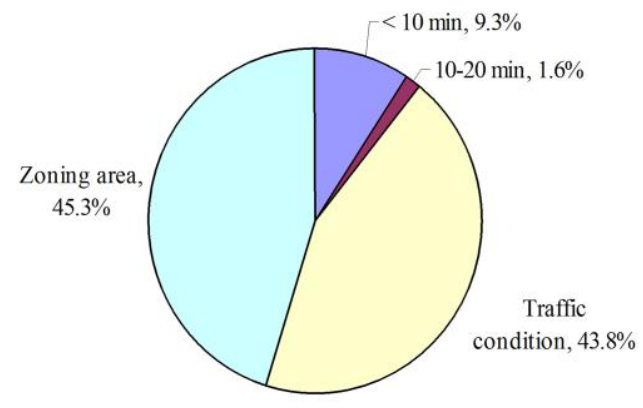

Figure 3. The Response Time to the Scene

\section{Service at Scene Location}

Figure 3 illustrates the factors influencing the response time. About $45.3 \%$ of the respondents believe that the time needed to arrive at accident locations depends on the response time zoning area while $43.8 \%$ response time is influenced by traffic conditions. Only $10.9 \%$ stated that the response time is generally below 20 minutes with $1.6 \%$ saying the it takes 10 to 20 minutes to arrive at the scene after emergency calls are made and only $9.3 \%$ said that it takes less than 10 minutes. All respondents stated that the responses to emergency calls are either "quick" $(68.8 \%)$ or "as expected" (31.2\%) as illustrated in Figure 4.

Nearly all respondents $(\mathrm{N}=64)$ except call centre employees agree that enough emergency staff are allocated at the scene location. However, they are also in agreement that more personnel are needed at

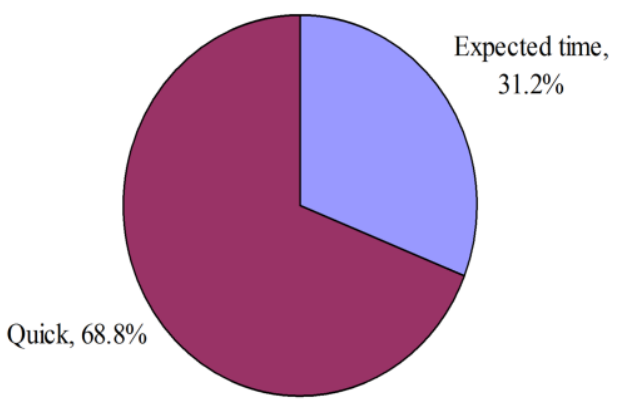

Figure 4. Emergency Speed-rating

Table 3. The Value of Percentages and Frequencies of Factors of Call Centre Services

\begin{tabular}{|c|c|c|c|c|c|c|c|}
\hline & Type of Service Factor & $\begin{array}{l}\text { Strongly } \\
\text { agree }\end{array}$ & Agree & Undecided & Disagree & $\begin{array}{l}\text { Strongly } \\
\text { disagree }\end{array}$ & $\mathrm{N}$ \\
\hline Q10a & $\begin{array}{l}\text { Call operator has been trained to manage emergency } \\
\text { calls }\end{array}$ & $\begin{array}{l}62.03 \% \\
(49)^{* * *}\end{array}$ & $\begin{array}{l}32.91 \% \\
(26)\end{array}$ & $\begin{array}{l}2.53 \% \\
(2)\end{array}$ & $\begin{array}{l}1.27 \% \\
(1)\end{array}$ & $\begin{array}{l}1.27 \% \\
(1)\end{array}$ & 79 \\
\hline Q10b & $\begin{array}{l}\text { Call operator must answer phone calls within } 4 \text { times } \\
\text { ring }\end{array}$ & $\begin{array}{l}36.71 \% \\
(29)\end{array}$ & $\begin{array}{l}29.11 \% \\
(23)\end{array}$ & $\begin{array}{l}10.13 \% \\
(8)\end{array}$ & $\begin{array}{l}13.92 \% \\
(11)\end{array}$ & $\begin{array}{l}10.13 \% \\
(8)\end{array}$ & 79 \\
\hline Q10c & $\begin{array}{l}\text { Call operator gives clear instructions to the caller for } \\
\text { further measures to address emergency situations }\end{array}$ & $\begin{array}{l}62.03 \% \\
(49)\end{array}$ & $\begin{array}{l}28.75 \% \\
(22)\end{array}$ & $\begin{array}{l}6.33 \% \\
(5)\end{array}$ & $\begin{array}{l}2.53 \% \\
(2)\end{array}$ & $\begin{array}{l}1.27 \% \\
(1)\end{array}$ & 79 \\
\hline Q10d & $\begin{array}{l}\text { To ensure the quality of information, call operator use } \\
\text { planned scripts prepared in advance }\end{array}$ & $\begin{array}{l}40.51 \% \\
(32)\end{array}$ & $\begin{array}{l}37.97 \% \\
(30)\end{array}$ & $\begin{array}{l}18.99 \% \\
(15)\end{array}$ & $\begin{array}{l}2.53 \% \\
(2)\end{array}$ & $\begin{array}{l}0 \% \\
(0)\end{array}$ & 79 \\
\hline Q10e & Call operator must be polite and respectful to the caller & $\begin{array}{l}83.54 \% \\
(66)\end{array}$ & $\begin{array}{l}15.19 \% \\
(12)\end{array}$ & $\begin{array}{l}0 \% \\
(0)\end{array}$ & $\begin{array}{l}0 \% \\
(0)\end{array}$ & $\begin{array}{l}1.27 \% \\
(1)\end{array}$ & 79 \\
\hline Q11a & $\begin{array}{l}\text { The information obtained from callers will be used to } \\
\text { ensure that the type of emergency response is suitable } \\
\text { to the needs of victims }\end{array}$ & $\begin{array}{c}84.81 \% \\
(67)\end{array}$ & $\begin{array}{c}13.92 \% \\
(11)\end{array}$ & $\begin{array}{l}0 \% \\
(0)\end{array}$ & $\begin{array}{l}1.27 \% \\
(1)\end{array}$ & $\begin{array}{l}0 \% \\
(0)\end{array}$ & 79 \\
\hline Q11b & $\begin{array}{l}\text { Quality information from the caller is useful for } \\
\text { emergency response team, so that they can go to the } \\
\text { location rapidly and be more responsive }\end{array}$ & $\begin{array}{l}86.08 \% \\
(69)\end{array}$ & $\begin{array}{l}12.66 \% \\
(10)\end{array}$ & $\begin{array}{l}0 \% \\
(0)\end{array}$ & $\begin{array}{l}1.27 \% \\
(1)\end{array}$ & $\begin{array}{l}0 \% \\
(0)\end{array}$ & 79 \\
\hline Q11c & $\begin{array}{l}\text { Call operator must provide the shortest distance and } \\
\text { information on the routes to the scene }\end{array}$ & $\begin{array}{l}48.10 \% \\
(38)\end{array}$ & $\begin{array}{l}16.46 \% \\
(13)\end{array}$ & $\begin{array}{l}30.38 \% \\
(24)\end{array}$ & $\begin{array}{l}5.06 \% \\
(4)\end{array}$ & $\begin{array}{l}0 \% \\
(0)\end{array}$ & 79 \\
\hline Q11d & $\begin{array}{l}\text { Call operator must provide further assistance to the } \\
\text { respondent at the scene such as additional manpower } \\
\text { and equipment }\end{array}$ & $\begin{array}{c}48.10 \% \\
(38)\end{array}$ & $\begin{array}{c}22.78 \% \\
(18)\end{array}$ & $\begin{array}{c}17.72 \% \\
(14)\end{array}$ & $\begin{array}{c}8.86 \% \\
(7)\end{array}$ & $\begin{array}{l}2.53 \% \\
(2)\end{array}$ & 79 \\
\hline & & \multicolumn{5}{|c|}{ Valid N (list wise) } & 79 \\
\hline
\end{tabular}

** number in ( ) is the frequency 
the scene for huge accidents. It can be seen from Table 4, that the "strongly agree" responses were $65.63 \%$ (42) for Q15c; $59.38 \%$ (38) for Q15a; $56.25 \%$ (36) for Q15d; and 45.31\% (29) for Q15b.

\section{Ambulance Transportation Service}

A number of questions on emergency ambulance transportation service from the accident location to the hospital emergency department were also asked. The questions were about: the response time; the type of ambulance used; transportation options to the emergency department; and the particular hospital involved. There are only two types of respondents required to answer questions in this section i.e. respondents who work at hospitals and Civil Defence Department ( $\mathrm{N}=31$ ).
Lower score shows higher frequency on the usage of the transportation mode. From Table 5, it is observable that government ambulances were the most used mode of transportation to transport the victims to hospitals. This is followed by civil defence ambulances, public vehicles, and the least using private and volunteer (St. John) ambulances. The response time also is very much related with the zoning and the traffic condition. Respondents (hospital and civil defence employees) were also asked on the factors involved in the transportation of victims to the hospitals. From Table 6, 80.65\% strongly agreed that victims are sent to the nearest hospitals, most of them disagree that victims are sent to the hospitals of their choice and victims are mostly informed about the hospital which they are to be transported to.

Table 4. The Percentages and Frequencies of Factor for on-the-scene Services

\begin{tabular}{|c|c|c|c|c|c|c|c|}
\hline & Type of Service Factor & $\begin{array}{l}\text { Strongly } \\
\text { agree }\end{array}$ & Agree & Undecided & Disagree & $\begin{array}{l}\text { Strongly } \\
\text { disagree }\end{array}$ & $\mathrm{N}$ \\
\hline Q15a & $\begin{array}{l}\text { Emergency staff should clearly explain } \\
\text { on what they will do to the victim }\end{array}$ & $\begin{array}{c}59.38 \% \\
(38)^{* * *}\end{array}$ & $\begin{array}{l}34.38 \% \\
(22)\end{array}$ & $\begin{array}{l}1.56 \% \\
(1)\end{array}$ & $\begin{array}{l}3.13 \% \\
(2)\end{array}$ & $\begin{array}{l}1.56 \% \\
(1)\end{array}$ & 64 \\
\hline Q15b & $\begin{array}{l}\text { Victims need to understand what } \\
\text { the emergency staffs are performing }\end{array}$ & $\begin{array}{l}45.31 \% \\
(29)\end{array}$ & $\begin{array}{l}40.63 \% \\
(26)\end{array}$ & $\begin{array}{l}10.94 \% \\
(7)\end{array}$ & $\begin{array}{l}1.56 \% \\
(1)\end{array}$ & $\begin{array}{l}1.56 \% \\
(1)\end{array}$ & 64 \\
\hline Q15c & $\begin{array}{l}\text { Emergency staff needs to be polite and be } \\
\text { respectful towards the victims }\end{array}$ & $\begin{array}{c}65.63 \% \\
(42)\end{array}$ & $\begin{array}{l}32.81 \% \\
(21)\end{array}$ & $\begin{array}{l}0 \% \\
(0)\end{array}$ & $\begin{array}{l}0 \% \\
(0)\end{array}$ & $\begin{array}{l}1.56 \% \\
(1)\end{array}$ & 64 \\
\hline Q15d & $\begin{array}{l}\text { Emergency staff still requires intensive } \\
\text { training to handle situations at the scene }\end{array}$ & $\begin{array}{c}56.25 \% \\
(36)\end{array}$ & $\begin{array}{c}29.69 \% \\
(19)\end{array}$ & $\begin{array}{c}12.50 \% \\
(8)\end{array}$ & $\begin{array}{c}1.56 \% \\
(1)\end{array}$ & $\begin{array}{l}0 \% \\
(0)\end{array}$ & 64 \\
\hline
\end{tabular}

$* *$ number in ( ) is the frequency

Table 5. Type of Ambulance used to Transport Victims

\begin{tabular}{lcc}
\hline \multirow{2}{*}{ Type of transportation } & \multicolumn{2}{c}{ No. of ranking } \\
\cline { 2 - 3 } & (min score) & $\mathrm{N}$ \\
\hline Government ambulance & 1.00 & 31 \\
Civil defence ambulance & 2.23 & 31 \\
Public vehicle & 2.29 & 31 \\
Privates ambulance & 4.13 & 31 \\
St. John ambulance & 4.68 & 31 \\
\hline
\end{tabular}

Table 6. The Percentages and Frequencies of the Ambulance Transportation Services

\begin{tabular}{|c|c|c|c|c|c|c|}
\hline Type of Service Factor & Strongly agr & e Agree I & Undecide & IDisagree & $\begin{array}{l}\text { Strongly } \\
\text { disagree }\end{array}$ & \\
\hline Q18aTransportation victims to the nearest hospital & $\begin{array}{c}80.65 \% \\
(25)^{* *}\end{array}$ & $\begin{array}{c}12.90 \% \\
(4)\end{array}$ & $\begin{array}{c}6.45 \% \\
(2)\end{array}$ & $\begin{array}{l}0 \% \\
(0)\end{array}$ & $\begin{array}{c}0 \% \\
(0)\end{array}$ & 31 \\
\hline Q18bTransportation victims to the selected hospital by providers & $\begin{array}{c}3.23 \% \\
(1)\end{array}$ & $\begin{array}{c}6.45 \% \\
(2)\end{array}$ & $\begin{array}{c}12.90 \% \\
(4)\end{array}$ & $\begin{array}{c}41.94 \% \\
(13)\end{array}$ & $\begin{array}{c}35.48 \% \\
(11)\end{array}$ & 31 \\
\hline Q18c Transportation to the hospital selected by victims & $\begin{array}{l}0 \% \\
(0)\end{array}$ & $\begin{array}{c}3.23 \% \\
\text { (1) }\end{array}$ & $\begin{array}{l}0 \% \\
(0)\end{array}$ & $\begin{array}{c}54.84 \% \\
(17)\end{array}$ & $\begin{array}{c}41.94 \% \\
(13)\end{array}$ & 31 \\
\hline Q18dInform victims which hospital to transport & $\begin{array}{c}45.16 \% \\
(14)\end{array}$ & $\begin{array}{c}29.03 \% \\
(9)\end{array}$ & $\begin{array}{c}9.68 \% \\
(3)\end{array}$ & $\begin{array}{c}12.90 \% \\
(4)\end{array}$ & $\begin{array}{c}3.23 \% \\
(1)\end{array}$ & 31 \\
\hline
\end{tabular}

\footnotetext{
*** number in ( ) is the frequency
} 


\section{Discussions}

Most respondents gave a high value for each item in the questionnaire on the services of ERS. A majority of respondents are familiar with MERS 999 besides GIRN, CCTV and CARS (Figure 1). Most of the respondents are high level officers (emergency staffs and supervisors) and have an experience of between two to five years in the ERS. All these indicate that the survey results are satisfactory and reliable. The respondents also stated that they manage the emergency calls well before performing the rescue operations. However, they are concerned about the response time, planning of the emergency rescue operations and the monitoring work (Figure 2). The call centre is the most significant part in the rescue system since it is the first to receive information on an accident and is responsible to relay the information to the relevant providers/departments. Providers usually receive emergency calls from the MERS 999 call centre as the number is the most known to the public (Table 2). This is an indication of success of the single emergency number for all cases around the country. The priority for the call centre is to gain useful information regarding the accident which can help providers to promptly and effectively perform the rescue mission (Table 3). Unfortunately, respondents seemed unsure about the statement "answer the call within 4 ringing" although this is part of the SOP.

For care at the scene, the respondents indicate that the response time depends on the "zoning area" and "traffic condition" rather than time value. They classified their response as "quick" and "expected time". This causes the response time obtained from the respondents to be higher than international standards [7]. However, respondents believed that response time is most important without the lack of better treatment to victims. In addition, the provider needs to be polite and respectful towards the victims in providing their service. The provider should also be clear on what they should perform and they need more training to provide better services.

After the rescue work at the scene, the victims will be transported to the hospital. The hospital and civil defence ambulances only transport the victims from the scene location to hospital. Government ambulances are the most used vehicle in transporting victims to the hospital (Table 5). During transportation, the victims to the hospital compared to other ambulances. The ambulance staffs will prioritise the need to bring victims to the nearest hospitals and the victims must be notified on their decisions. In Malaysia, the victims are not allowed to chose which hospital they are to be taken to (Table 6). Only after the emergency treatment that they can transfer to other hospitals for further or better treatment.
This study covers only the ERS providers' services from receiving the emergency calls until the transportation of victims to the hospital. This is the first such study in Malaysia, and the main problem is the absence of a standard as for comparison. There are some constraints to determine the effectiveness of services provided by emergency workers because there are no data or references available. The only available data is the patients' satisfaction on ambulance response time from previous literatures. The surveys should be expanded to include more respondents from every provider and the questions must be more specific to include all particular tasks of different service providers. Future studies should also compare the viewpoints of the providers and the public satisfaction. This will enable researchers and authorities to identify the gap between the existing service and the demands and needs of the public as providers ought to be responsible and accountable to the public as well as customers (patients). The services quality (SERVQUAL) enables the public and providers to identify critical areas for improvement in the service delivery [9]. Future investigations and studies should address these issues. The result of this study points that there is a need to improve the providers' services especially in response time and the training of emergency personnel. The providers need to further improve their services so that the public are satisfied and their perceptions towards the providers will improve [4].

\section{Conclusion}

Overall, the emergency services provider respondents, in the surveys conducted between September and October 2010 seemed to be good at their job. Most of the variables studied seemed positive from the providers' viewpoint. All providers - police, hospital ambulance, fire and rescue, and civil defence as well as MERS 999 call centre - perform their task according to the SOP. The results of this study show that effective services are provided by the MERS 999 who gather the relevant information and quickly forward them to the relevant providers to ensure a prompt response. At the accident location, the emergency workers are courteous and respectful, know what their responsibilities and what to do, but still need more intensive training to better respond to the emergency. In getting the victims to the hospital for further emergency treatment, ambulance personnel would choose to bring the victims to the nearest hospital rather than hospital of the victims' choosing.

The suggestions to improve the response time as an important factor were given by the respondents. They also feel that the ERS can still be improved to keep up with the improving technologies and the knowledge of the emergency workers can still be improved through continuous training while the public should be given some education on emergency 
situation handling to complement the works of the providers. Furthermore, respondents believe that the existing facilities and equipments should be improveed. Another issue that needs change and improvement is the coordination and cooperation between the providers to ensure more efficient and effective services towards reducing casualties resulting from road accidents. The results of this study will be used as a baseline to evaluate any future improvement in the services of the ERS in Malaysia.

\section{Acknowledgements}

The authors would like to thank the Ministry of Higher Education, Malaysia (MOHE), University Tun Hussein Onn Malaysia (UTHM) and Saga University of Japan, for their support during the completion of this research.

\section{References}

1. Law T.H., Radin Umar R.S., and Wong S.V., The Malaysian Government's Road Accident Death Reduction, International Association of Traffic and Safety Science Research, 29(1), 2005, pp. 4249.

2. Anisah A., Chew K.S., Shaharuddin Shah C.H., and Hisamuddin N.A., Patients Perception of the Ambulance Services at Hospital Universiti Sains Malaysia, Singapore Medical Journal, 49(2), 2008, pp. 631-635.

3. Hisamuddin N.A., Hamzah M. S., Holliman J. S., Prehospital Emergency Medical Services in Malaysia, The Journal of Emergency Medicine, 32(4), 2007, pp. 415-421.
4. Mustaffa, A.A. and Hokoa K., Public Satisfaction of the Emergency Response Systems in Road Accidents: Case Study in Johor Bahru, Malaysia, International Journal on City Planning, Korea Planner Associate, 2011, pp. 293-302.

5. Saibon I., Eng H.S., Krishnan B., Siti Nooraini A., Murad N., Pathnathan A., and Choy C.Y., A Study of Patients Satisfaction with the Emergency Department of Hospital Universiti Kebangsaan Malaysia (HUKM), Med. and Health J., 3(1), 2008, pp. 7-13.

6. Mohd Shaharuddin C.H., Mohd Ismail I., and Syed Mohsin S.S., Ambulance Response Time and Emergency Medical Dispatcher Program: A Study in Kelantan, Malaysia, Southeast Asia J. Trop. Med. Public Health, 39(6), 2008, pp. 11501154.

7. Mohd. Shaharudin C.H., Ahmad R., Hisamuddin N.A., Wati Pardi K., Jaafar N., Wan Adnan W.A., Jaalam K., and Jamalullail M.S., Ambulance Services at Hospital Universiti Sains Malaysia and Hospital Kota Bharu: A Retrospective Study of Calls, Malaysian Journal of Medical Sciences, 2(2), 2005, pp. 34-42.

8. Ani M.S, Fakrul Razi A., and Daud M., Evolution of Emergency Management In Malaysia, Journal of Contingencies and Crisis Management, 9(1), 2001, pp. 46-53.

9. Ramseook-Munhurrun P., Lukea-Bhiwajee S.D., and Naidoo P., Service Quality in the Public Service, International Journal of Management and Marketing Research, 3(1), 2010, pp. 37-50. 